\title{
Kosmetik Antipolusi : Kosmetik Zaman Now
}

\author{
Eka Riza Maula \\ Apoteker Penanggung Jawab di Industri Kosmetik di Surabaya \\ email: eka.riza13@gmail.com
}

\section{Abstrak :}

Polusi di lingkungan mempunyai dampak negatif pada kesehatan manusia. Selain itu, juga menyebabkan dampak negatif terhadap kulit diantaranya, penuaan kulit, pigmentasi kulit, dan jerawat. Paparan polusi juga menjadi isu serius meliputi dermatitis atopik, psoriasis, dan bahkan kanker kulit. Adanya paparan polutan akibat kontaminasi lingkungan akan meningkatkan produksi reactive oxygen species (ROS), aktivasi Aryl hydrocarbon receptor (AhR), dan menginduksi respon inflamasi. Beberapa zat aktif dapat digunakan sebagai bahan antipolusi dan bekerja melalui beberapa cara diantaranya, Membersihkan kulit dan pembentukan lapisan film, Memperkuat lapisan pelindung kulit dan meningkatkan kelembaban, Meningkatkan kandungan Antioksidan, Mencegah degradasi kollagen/Elastin, Kontrol pigmentasi, dan Mengurangi Inflamasi.

Keyword : Kosmetik, polusi, antioksidan, pigmentasi

\section{Pendahuluan}

Tingkat polusi di udara secara konstan mengalami peningkatan diseluruh dunia. Data WHO pada tahun 2016 menunjukan bahwa lebih dari 3 juta orang setiap tahun meninggal akibat polusi, serta sekitar $90 \%$ orang hidup di area yang tidak sesuai dengan guideline kualitas udara WHO.

Sumber utama polusi berasal dari partikel-partikel, polycyclic aromatic hydrocarbon (PAHs), Volatile organic compound (VOC), nitogen dan sulfur oxide, kabon monoksida, ozon, dan logam berat. Umumnya polusi bersumber dari industri dan buangan kendaraan bermontor. Selain itu, kualitas udara di dalam ruangan juga menjadi faktor penting. Polusi didalam ruangan bisa berasal dari paparan karbon monoksida, nitrogen dioxide, atau senyawa VOC yang berasal dari asap rokok, cat tembok, dan pengharum ruangan(1).

Polutan di lingkungan telah diketahui mempunyai dampak negatif pada kesehatan manusia. Paparan polutan yang berlebihan dapat menyebabkan banyak masalah kesehatan meliputi penyakit jantung dan paru-paru serta, peningkatan resiko infeksi bakteri dan virus. Kontaminasi lingkungan juga menyebabkan dampak negatif terhadap kulit diantaranya, penuaan pada kulit, pigmentasi kulit, dan jerawat. Paparan polusi juga menjadi isu serius meliputi dermatitis atopik, psoriasis, dan bahkan kanker kulit. Polutan juga dapat melemahkan fungsi pertahanan kulit dan penetrasinya ke dalam kulit menyebabkan toksisitas sistemik pada organ tubuh lain(1). Oleh karena itu, muncul produk-produk kosmetik antipolusi yang berfungsi melindungi kulit dari dampak negatif polutan serta membantu mengembalikan fungsi pertahanan kulit(1). 
Dalam dua tahun terakhir perkembangan kosmetik anti-polusi sedang menjadi trend di beberapa negara, khususnya negara asia yang memiliki tingkat polusi udara tinggi misalnya negara shanghai dan beijing di china, new delhi dan bangalore di india. Meskipun negara bagian eropa dan amerika utara memiliki tingkat polusi yang lebih rendah namun, akhir-akhir ini tingkat polusi yang melintasi benua afrika meningkat secara signifikan. Sehingga, kosmetik antipolusi berkembang tidak hanya di wilayah asia pasifik tapi juga berkembang di negara barat(2).

Faktor-faktor yang menyebabkan peningatan trend kosmetik antipolusi diantaranya :

- Kualitas udara yang buruk khususnya di negara-negara metropolitan di asia dan negara barat.

- Pertumbuhan penduduk

- Peningkatan kesadaran dan perhatian tentang efek buruk polusi lingkungan pada kesehatan, kesejahteraan dan kecantikan.

- Peningkatan penelitian terkait efek polusi lingkungan terhadap kulit

- Banyak dikembangkannya bahan-bahan aktif untuk melindungi kulit

\section{Dampak negatif polutan pada kulit dan mekanisme aksinya}

Polusi mempunyai dampak besar pada sel-sel kulit. Adanya paparan polutan akibat kontaminasi lingkungan akan meningkatkan produksi reactive axygen species (ROS) yang akan mengurangi jumlah antioksidan di kulit, hal ini akan menganggu keseimbangan redox dan menyebabkan stress pada sel-sel kulit. Beberapa polutan juga berpenetrasi melalui stratum korneum menuju lapisan kulit yang lebih dalam. Polutan yang berpenetrasi tersebut bekerja sebagai ligan untuk Aryl hydrocarbon receptor (AhR) yang akan menginduksi reaksi inflamasi di kulit, meningkatnya produksi sitokin-sitokin proinflamasi seperti interleukin $1 \beta$ atau interleukin 8 , yang menghasilkan lesi pada kulit memperburuk penampilan kulit(1).

Menurut beberapa penelitian, polusi dapat merusak pertahanan kulit, menyebabkan penurunan kadar vitamin $\mathrm{E}$ dan squalene, rusaknya kolagen dan elastin yang akan memperburuk kerusakan kulit seperti kulit kering, hiperpigmentasi, penuaan, sekresi sebum berlebih, inflamasi dan kulit sensitif, eczema, dan atopic dermatitis. Pembentukan noda hitam di wajah yang juga disebabkan karena peningkatan polusi udara kendaraan(2).

Polutan menginduksi stress oksidative, produksi ROS, dan sekresi sitokin-sitokin pro-inflamasi, menghasilkan peroxidasi lipid dan kerusakan DNA. Selanjutnya, meningkatkan matrix metallo proteinases (MMPs)-1,-2, dan -9, yang merusak kolagen(2).

\section{Bahan aktif yang berfungsi sebagai antipolusi dan mekanismenya}

Beberapa zat aktif dapat digunakan sebagai bahan antipolutan di beberapa produk kosmetika, bahan aktif tersebut digolongkan berdasarkan mekanisme aksinya. Secara umum produk kosmetik antipolusi memiliki desain atau tujuan penggunaan yaitu(2) :

- Mengurangi partikel-pertikel yang menempel di kulit melalui proses cleansing atau exfoliating

- Mencegah deposisi dan penetrasi pollutan pada kulit

- Mengembalikan dan memperkuat struktur dan fungsi lapisan pelindung kulit (skin protective barrier)

- Mengurangi trans epidermal water loss (TEWL) dan meningkatkan kelembaban kulit

- Mengisi cadangan antioksidan 
- Mengurangi inflamasi

- Mengontrol melanogenesis

- Meningkatkan sintesis kolagen atau elatin

- Melindungi kulit dari bahaya sinar UV

Secara umum formulasi kosmetik antipolutan dikembangkan dengan menggabungkan beberapa bahan aktif dengan mekanisme aksi yang berbeda. Zat aktif yang digunakan dibedakan menjadi beberapa golongan diantaranya(2) :

\section{Membersihkan kulit dan pembentukan lapisan film.}

Langkah awal untuk melindungi bahaya pollutan yaitu mencegah dan menghilangkan deposisi dan penetrasi partikel pollutan pada kulit(2).

Active charcoal (porosity tinggi) : manfaat charcoal membantu untuk menghilangkan toxin pollutan dari kulit. Selain itu, absorben padat lainnya diantaranya kaolin, magnesium aluminum silicate, dan scub dari kopi dan beras juga bisa digunakan sebagai produk antipolusi

Lecithin, acrylic acid/ acryl amidomethyl propane, sulfonic acid cocpolymer, dimethyl methoxy chromanol, xanthan gum, glyceryl caprylate dan diisopropyl adipate : senyawa aktif ini berfungsi memberikan lapisan perlindungan (barrier) antara kulit dengan senyawa-senyawa berbahaya sehingga, mencegah akumulasi partikel-partikel pollutan pada epidermis.

\section{Memperkuat lapisan pelindung kulit dan meningkatkan kelembaban}

Polusi dapat merusak dan melemahkan lapisan pelindung alami kulit yang menyebabkan peningkatan penetrasi pollutan lebih tinggi dan dalam pada lapisan kulit, hal ini akan mempengaruhi integritas struktur kulit, meningkatkan TEWL, dan berkurangnya kelembaban kulit(2)

Ekstrak Tremella Fuciformis : zat aktif ini mengandung polysaccharida yang akan meningkatkan kelembaban dan membentuk lapisan film forming pada kulit. Zat ini melindungi kulit dari pollutan dengan pembentukan lapisan tipis yang melembabkan kulit. Efek moisturizing zat aktif ini lebih efektif dibandingkan hyaluronic acid.

Ekstrak Chondrus Crispus (Red Algae) : kandungan carrageenan yang tinggi pada alga ini berfungsi membentuk lapisan film untuk melindungi kulit yang juga dikenal sebagai "second skin". Ekstak ini berfungsi sebagai instan film former karena kandungan polysakarida yang tinggi. Bahan aktif ini juga melindungi kulit dari kekeringan dan iritasi melalui mekanisme yaitu menjaga natural moisturizing factor (NMF) kulit dan mengurangi TEWL.

\section{Meningkatkan kandungan Antioksidan}

pollutan lingkungan dapat menginduksi oksidatif stress dan produksi ROS, hal ini dapat merusak protein sel, DNA, dan membran sel sehingga menyebabkan wrinkles atau kerutan wajah dan kulit kering. Penggunaan senyawa aktif yang mengandung antioksidan dan metal chelating agent dalam formula kosmetik dapat meningkatkan mekanisme zat aktif lain sebagai anipolusi.

Ekstrak Camellia sinensis (White tea) : bahan aktif ini telah diteliti mengandung antioksidan flavonoid yang menetralkan hingga $80 \%$ radikal bebas, melindungi membran sel dari senyawa pollutan dan efek buruk lingkungan. 
Myrtle Leaf extact : bahan aktif dengan kandungan flavonoid yang larut air dan tannin, merupakan anti oksidan yang sangat poten untuk melindungi kulit. Ekstrak myrtle membantu oksigenasi, menetralisir efek pollutan dan radikal bebas dengan kemampuannya membentuk kompleks.

\section{Mencegah degradasi kollagen/ Elastin}

Polusi diketahui dapat merusak struktur protein seperti kollagen dan elastin. Zat aktif yang dapat mencegah degradasi kollagen dan elastin dapat meningkatkan efikasi produk antipolusi.

Ekstrak Microalgae Nannochloropsis Occulata : bahan aktif ini kaya akan kandungan vitamin C, vitamin B12, polysaccharida-pullulan, senyawa tersebut membantu memperbaiki dan menjaga membran ekstraselullar (lapisan luar kulit). Ekstrak ini memberi efek mengencangkan kulit secara instan dan jangka panjang. Hal ini karena ekstrak ini membantu menstimulasi pembentukan collagen 1 yang berperan penting pada jaringan kulit.

\section{Kontrol pigmentasi}

Polusi mempengaruhi sintesis melanin dan dapat menghasilkan bekas kehitaman di wajah (dark spot). Zat aktif yang meregulasi jalur sintesis melanin dapat mencegah efek polusi di lingkungan.

Ekstrak lepidium sativum, mengandung sulforaphane yang merupakan antioksidan yang kuat. Ekstrak ini secara efektif menghambat pigmentasi melalui 2 tahapan yaitu menetralisir ROS dan menghambat $\alpha-\mathrm{MSH}$ (hormon yang menstimulasi pigmentasi kulit).

Senyawa alam yang mengandung resveratrol dapat mengurangi sintesis melanin. Senyawa ini mengurangi sintesis melanin melalui beberapa jalur yaitu : menghambat tyrosinase, regulasi MCR1 (reseptor $\alpha-\mathrm{MSH}$ ), mempengaruhi fungsi dan maturisasi melanosome, mengurangi transport melanosome menuju melanocytes. Senyawa ini memberi efek whittening yang terbaik serta membuat kulit tampak lebih cerah.

\section{Mengurangi Inflamasi}

Pollutan dapat menginduksi sekresi sitokin-sitokin pro-inflamatory seperti TNF- $\alpha$, IL-1 $\alpha$, dan IL-8 yang akan meningkatkan inflamasi kulit, kemerahan dan penuaan kulit. Penggunaan antiinflamasi pada formula anti polusi akan mengurangi efek buruk akibat polusi.

Ekstrak akar Zingiber Officinale (Ginger) atau jahe. Ekstrak ini digunakan sebagai anti-irritan dan meningkatkan tekstur kulit. Kandungan di ekstrak ini dapat menghaluskan kerutan wajah. Mekanisme aksinya melalui jalur arachidonic acid yang menghasilkan aksi berupa anti-inflamasi, analgesik dan antipiretik sehingga mengurangi kemerahan dan iritasi kulit.

Ekstrak rubus idaeus (American red rasberry) diketahui menghambat aktivitas antiinflamasi disebabkan karena kandungan flavonoid dan anthocyanin yang tinggi.

\section{Kesimpulan}

Polusi di lingkungan mempunyai dampak negatif pada kesehatan manusia. Selain itu, juga menyebabkan dampak negatif terhadap kulit diantaranya, penuaan kulit, pigmentasi kulit, dan jerawat. Paparan polusi juga menjadi isu serius meliputi dermatitis atopik, psoriasis, dan bahkan kanker kulit. 
Adanya paparan polutan akibat kontaminasi lingkungan akan meningkatkan produksi reactive axygen species (ROS), aktivasi Aryl hydrocarbon receptor (AhR), dan menginduksi respon inflamasi. Beberapa zat aktif dapat digunakan sebagai bahan antipolusi dan bekerja melalui beberapa cara diantaranya, Membersihkan kulit dan pembentukan lapisan film, Memperkuat lapisan pelindung kulit dan meningkatkan kelembaban, Meningkatkan kandungan Antioksidan, Mencegah degradasi kollagen/ Elastin, Kontrol pigmentasi, dan Mengurangi Inflamasi.

\section{Daftar Pustaka}

Rembiesa, Jadwiga et al. 2018. The Impact of pollution on skin and proper efficacy testing for anti-pollution claims.Cosmetics 2018. mdpi.com/journal/cosmetics.

Mistry, Niraj. 2017. Guidelines fo Formulating Anti-Pollution products. Cosmetics 2017. mdpi.com/journal/cosmetics. 